\title{
COMMENT
}

\section{INFORMING THE JURY OF THE LEGAL EFFECT OF SPECIAL VERDICT ANSWERS IN COMPARATIVE NEGLIGENCE ACTIONS}

During the past decade numerous states with comparative negligence systems have permitted judges to inforn juries of the legal effect of special verdict answers in negligence actions. ${ }^{1}$ These states have reversed the trend of judicial decisions that commenced before the turn of the century in Wisconsin. The Wisconsin decisions leeld that it is reversible error to inform the jury in any civil case of the legal effect of special verdict answers." The "Wisconsin rule" was predicated on the objective of special verdicts-to attain findings of fact untainted by prejudice or sympathy for or agamst one of the parties. ${ }^{3}$ If juries are told about the effect their determinations will lave on the outcome of the case, then they may adjust the special verdict answers to comport with a predetermined outcome. ${ }^{4}$ Although the rule against informing protects agamst this possible jury bias, nearly a dozen states have recently perceived the need to abrogate this rule in coinparative negligence cases.

This comment discusses the developinent and application of the Wisconsin rule. The comment then describes the recent movement toward rejection of the rule and analyzes the arguments both for and agamst its application. After einphasizing the compatibility of the Wisconsin rule with the equitable goals of the comparative negligence principle, the comment concludes by endorsing the rule and recommending procedural clianges that will assist the courts in fulfilling the purposes of the special verdict scheme.

1. See text accompanying notes $63-81$ infra.

2. See text accompanying notes $26-46$ infra.

3. See J. Frank, Courts on Trial 141-42 (1949).

4. See generally Note, Informing the Jury of the Legal Effect of its Answers to Special Verdict Questions Under Kansas Comparative Negligence Law-A Reply to the Masses: $A$ Case for the Minority View, 16 WASHBURN L.J. 114 (1976). 


\section{The Emergence of Comparative Negligence}

The doctrine of comparative negligence has gained increasing popularity aunong legal commentators, state courts, and legislatures as a means of mitigating the harshness of the common law contributory negligence defense. A system of contributory negligence completely bars a plaimtiff from recovery against a negligent defendant if the plaintiff's negligence is a proximate cause of his danages. ${ }^{5}$ A system of comparative negligence apportions the relative negligence of the parties and reduces the plaintiff's recovery according to his degree of fault. 6 Although the defense of contributory negligence remaims under the comparative negligence system, the plaimtiff's negligence reduces, rather than bars, his award of damages. ${ }^{7}$ The comparative negligence system is fairer than the system based on the all-or-nothing contributory negligence defense because under the forner a negligent plaintiff may recover for damages proximately caused by the defendant's negligence.

Jurisdictions have adopted the principle of coinparative negligence by statutory enactment ${ }^{8}$ and judicial decision. ${ }^{9}$ In addition, a number

5. Butterfield v. Forrester, 103 Eng. Rep. 926 (K.B. 1809). To ameliorate the unfairness of the all-or-nothing defense, numerous exceptions have been carved out of the contributory negligence doctrine. See V. SchwarTz, Comparative Negligence § 1.2, at 5-9 (1974); Prosser, Comparative Negligence, 51 MiCH. L. REv. 465, 470-75 (1953).

6. Througlout this comment, the terms "negligence" and "fault" are used interchangeably. A fine distinction exists, however, between the terms as used by the state courts. A comparative fault system demands the quantification of all nonintentional tortious conduct. See, e.g., ARK. STAT. ANN. $\$ \$ 27-1763$ to -1765 (1979). A comparative negligence system mandates an apportionment of damages only when ordinary negligence has been committed. V. SCHWARTZ, COMPARAtive Negligence § 5.3, at 105 (1974); see, e.g., Colo. Rev. Stat. § 13-21-111 (1973 \& Supp. 1980).

7. But see text accompanying notes 13-14 infra. In cases that implicate the conduct of both parties, the trier of fact determines the relative responsibility of the parties in causing the harm. This determination typically imvolves allocating specific percentages of negligence among the parties, with the sum necessarily equaling $100 \%$. These figures are then nsed to remit the plaintiffs total damages to arrive at the amount of his recovery. See V. SchwarTZ, Comparative NEGLIGENCE $§ 3.2$ (1974).

8. Federal Employers' Liability Act, 45 U.S.C. §53 (1976); Jones Act, 46 U.S.C. § 688 (1976); Death on the Higlı Seas Act, 46 U.S.C. \& 766 (1976); ARK. STAT. ANN. § 27-1765 (1979); Colo. Rev. STat. \& 13-21-111 (1973 \& Supp. 1980); Conn. Gen. STAT. § 52-572h (1981); HawaII Rev. STAT. § 663-31 (1976); IDAHo CODE § 6-801 (1979); Kan. STAT. ANN. § 60-258a (1976); LA. Civ. Code ANn. art. 2323 (West Supp. 1981); Me. Rev. Stat. ANN. tit. 14, $\$ 156$ (1980); Mass. ANN. Laws ch. 231, §85 (Michie/Law. Co-op Supp. 1981); MinN. Stat. §604.01 (1978); Miss. Code ANn. § 11-7-15 (1972); Mont. Rev. Codes ANN. § 58-607.1 (Supp. 1977); Neb. Rev. STAT. § 25-1 151 (1979); NEv. REv. STAT. § 41.141 (1979); N.H. REv. STAT. ANN. § 507:7-a (Supp. 1979); N.J. Stat. AN. \& 2A:15-5.1 (West Supp. 1981); N.Y. CIv. Prac. LAw \& 1411 (McKinney 1976); N.D. Cent. Code § 9-10-07 (1975); OHIo Rev. CODE ANN. § 2315.19 (Page Supp. 1980); OKLA. STAT. tit. 23, § 13 (1980); OR. Rev. STAT. § 18.470 (1979); 42 PA. Cons. STAT. § 7102 (1978); R.I. Gen. Laws \& 9-20-4 (Supp. 1980); S.D. Comp. Laws ANn. \& 20-9-2 (1979); TeX. Rev. Civ. Stat. ANN. art. 2212a (Vernon Supp. 1980); Utah Code ANN. \$ 78-27-37 (1953); Vt. Stat. ANN. tit. 
of state courts have recognized their inherent power to modify the contributory negligence defense by adoptimg a comparative fault system, but have chosen to defer to the legislature. ${ }^{10}$

Comparative negligence systems take two basic forms: pure and modified. ${ }^{11}$ The forms differ regarding whether the plaintiff's percentage of the total fault will bar him from recovery. A pure comparative negligence system guarantees that a negligent plaintiff will recover damages from a negligent defendant regardless of the plaintiff's degree of causal responsibility for the accident. Under the pure form the plaintiff's total damages are reduced in proportion to the percentage of his negligence. This method of calculating damages is the fairer of the two because the amount of recovery is derived directly from the defendant's relative fault. ${ }^{12}$

Modified comparative negligence incorporates the primciple that a party who is inore at fault should not be allowed to recover from one less at fault. ${ }^{13}$ Consequently, a barrier is imposed at either the $50 \%$ or the $51 \%$ negligence level which prevents the recovery of any damages. There are two types of modified comparative negligence systems. Under the "49\%" type the plaintiff cannot recover dainages if his negligence is as great as or greater than that of the defendant; under the

12, § 1036 (Supp. 1980); WASH. REv. CODE $§ 4.22 .010$ (1979); WIS. STAT. § 895.045 (1977); WYO. STAT. \& 1-1-109 (1977).

9. United States v. Reliable Transfer Co., 421 U.S. 397 (1975) (admiralty); Kaatz v. State, 540 P.2d 1037 (Alaska 1975); Li v. Yellow Cab Co., 13 Cal. 3d 804, 532 P.2d 1226, 119 Cal. Rptr. 858 (1975); Hoffman v. Jones, 280 So. 2 d 431 (Fla. 1973); Alvis v. Ribar, 85 IIl. 2d 1, 421 N.E.2d 886 (1981); Placek v. City of Sterling Heights, 405 Mich. 638, 275 N.W.2d 511 (1979); Scolt v. Rizzo, No. 13,235 (N.M. Feb. 12, 1981), affg Claymore v. City of Albuquerque, No. 4804 (N.M. Ct. App. Dec. 9, 1980); Bradley v. Appalachian Power Co., 256 S.E.2d 879 (W. Va. 1979).

Georgia has the oldest judicially-adopted comparative negligence system presently in existence. See Flanders v. Meath, $27 \mathrm{Ga} .358$ (1858). The Georgia scheme actually is based on a strained construction of a comparative fault statute expressly applicable only in railroad accident cases. See Smith v. American Oil Co., 77 Ga. App. 463, 49 S.E.2d 90 (1948).

10. See, e.g., Golden v. McCurry, 392 So. 2d 815, 817 (Ala. 1980); Fuller v. Buhrow, 292 N.W.2d 672, 674 (Iowa 1980); Epple v. Western Auto Supply Co., 557 S.W.2d 253, 254 (Mo. 1977). See generally Fleming, The Supreme Court of Califomia 1974-1975-Foreword: Compara. tive Negligence At Last-By Judicial Choice, 64 CALIF. L. Rev. 239 (1976); James, Kalven, Keeton, Le Flar, Malone, \& Wade, Comments on Maki v. Frelk-Comparative v. Contributory Negligence: Should the Court or Legislature Decide?, 21 VAND. L. REv. 889 (1968); Schwartz, Comment: Judicial Adoption of Comparative Negligence-The Supreme Court of California Takes a Historic Stand, 51 IND. L.J. 281 (1976).

11. A third variation of comparative negligence is the slight/gross form, in which a negligent plaintiff recovers only when his neghigence is slight in conparison with that of the defendant. This form is used in only two states, see NeB. Rev. StaT. § 25-1151 (1979); S.D. Comp. Laws ANN. \$ 20-9-2 (1979), and has been criticized by legal commentators. See Prosser, supra note 5, at 48689.

12. See Kirby v. Larson, 400 Mich. 585, 642-44, 256 N.W.2d 400, 428-29 (1977).

13. V. SchWartZ, Comparative NeGligenCE § 3.5(B), at 78 (1974). 
"50\%" type the plaintiff cannot recover if his negligence is greater than the defendant's, but can recover if his negligence is as great as the defendant's. ${ }^{14}$

Legal commentators have debated the advantages and disadvantages of the pure and the modified forms of comparative negligence. Proponents of the modified form contend that a plaintiff should not be able to profit from his own wrong. ${ }^{15}$ Proponents of the pure form poimt out that the $50 \%$ or $51 \%$ cut-off of modified comparative negligence imposes an arbitrary barrier affecting the determination of liability. They argue that the modified form does not eliminate the contributory negligence defense, but merely shifts the complete bar to recovery to a different level. ${ }^{16}$ Because of the relative merits of each system, however, both forms must be considered in an analysis of comparative negligence trial procedure.

\section{The Use of Special Verdicts In Comparative NEGLIGENCE ACTIONS}

In most comparative negligence cases a jury determines the relative percentages of negligence of the parties and the total amount of the

14. The two variations of modified comparative negligence reach different results only in cases that assess the plaintifi's negligence at exactly $50 \%$. This difference is more significant than one miglit expect, given the high frequency of 50-50 apportionments. See note 34 infra.

15. Ghiardi, Comparative Negligence-The Case Against a Mississippi Type Statute, 10 For THE DEF. 61, 64 (1969). Critics of pure comparative negligence also assert that the result under that form of negligence too often depends not on the relative fault of the parties, but on the amount of damages suffered. See Bradley v. Appalachian Power Co., 256 S.E.2d 879, 883 (W. Va. 1979). For example, if the negligence is apportioned at $80 \%$ and $20 \%$ and the damages at $\$ 100,000$ and $\$ 10,000$ to the plaintiff and the defendant respectively, the result will be a net recovery by the plaintiff of $\$ 12,000$. Although the amount recovered by the plaintiff is a small portion of his damages, the defendant, whose conduct is much less objectionable, is completely unremibursed.

16. Li v. Yellow Cab Co., 13 Cal. 3d 804, 827, 532 P.2d 1226, 1242, 119 Cal. Rptr. 858, 874 (1975). It is difficult to justify the vastly different treatment in a modified systen between cases in which the plaintiff is sliglttly more neghigent than the defendant and those in which the plaintiff is slightly less negligent than the defendant. Keeton, Comments on Maki v. Frelk-Comparative v. Contributory Negligence: Should the Court or Legislature Decide?, 21 VAND. L. REv. 906, 911 (1968).

Pure comparative negligence is consistent with the spirit of comparative negligence because it permits the "more wrong" plaintiff to recover from the "less wrong" defendant and sets the recovery at an amount directly proportionate to the defendant's fault. Although the plaintiff wins a judgment, the amount of damages recoverable is sharply diminished. See Vincent v. Pabst Brewing Co., 47 Wis. 2d 120, 126, 177 N.W.2d 513, 515 (1970) (quoting Campbell, Wisconsin Law Governing Automobile Accidents-Part II, 1962 WIS. L. REv. 557, 569).

The pure versus modified comparative negligence debate has also focused on the effects the two forms of negligence have on judicial administration. Administrative coneerns, however, should not outweigh the substantive policy considerations that underlie the form of comparative negligence to be adopted. 
plaintiff's daunages. ${ }^{17}$ The court then performs a mathematical computation to reduce the damages im proportion to the plaintiffs degree of negligence in order to arrive at the judgment amount. ${ }^{18}$ Because of the numerical specificity of the jury's findings of fact, special verdict questions or special imterrogatories are helpful to the performance of the jury's task and the interpretation of the findings by the court. ${ }^{19}$

The jury's use of special findings in a comparative neghigence action facilitates a logical consideration of the fáctual issues in a case ${ }^{20}$ and independent inquiries imto the issues of negligence and damages. ${ }^{21}$ Moreover, by removing the results of the jury's dehberations from the "cloak of secrecy" of the general verdict, ${ }^{22}$ the use of special verdicts enables both trial and appellate courts to monitor closely the jury's performance of its designated task. By permitting full disclosure of the findings of fact, special verdict submission fits neatly into the compara-

17. These numerical findings are often referred to as the ultimate findings of fact. They represent a quantification of the jury's determinations of culpability and causality of the conduct of the plaintiff and the defendant.

18. In states that require the jury to return only a general verdict, see note 23 infra, the jury performs the mathematical reduction to ascertain the judgment amount.

19. See Brown, Federal Special Verdicts: The Doubt Eliminator, 44 F.R.D. 338, 346 (1967). Special verdicts involve the submission to the jury of specific questions which require written answers that constitute the findings of fact in a civil case without a rendering by the jury of a general verdict in favor of a party. This procedure differs from the submission of general verdicts accompanied by special interrogatories, whereby the jury answers specific questions and also renders a verdict for or against each party. See generally Morgan, A Brief History of Special Verdicts and Special Interrogatories, 32 YaLE L.J. 575 (1923); Sunderland, Verdicts, General and Special, 29 YALE L.J. 253 (1920). For a thorough discussion of the advantages of special verdict submission, see Skidmore v. Baltimore \& O.R.R., 167 F.2d 54 (2d Cir.), cert. denied, 335 U.S. 816 (1948).

20. Florida East Coast Ry. v. Lawrence, 328 So. 2d 249, 255 (Fla. Dist. Ct. App. 1976) (quoting Timmons \& Silvis, Pure Compurative Negligence in Florida: $A$ New Adventure in the Common Law, 28 U. MIAMI L. REv. 737, 802 (1974)), rev'd on other grounds, 346 So. 2d 1012 (Fla. 1977).

21. V. SchwartZ, Comparative Negligence $\$ 17.4$, at 289 (1974). Theoretically, once the relative responsibility of the parties has been quantified, the elements involved in that computation should not affect the determination of damages.

One article describes the "double deduction," an undesirable phenomenon that may occur when the negligence and damages issues are not considered separately. The author observes a tendency for the jury, either consciously or unconsciously, to reduce the gross damages figure to represent something less than the fotal damages suffered by the plaimtiff. The judge, upon receiving the special verdict answers, then reduces the damages a second time, resulting in a deflated recovery. Nixon, The Actual "Legislative Intent" Behind New Hampshire's Comparative Negligence Statute, 12 N.H.B.J. 17, 27-28 (1969); see, e.g., Schlein v. Florida East Coast Ry., 339 So. $2 \mathrm{~d} 1142$ (Fla. Dist. Ct. App. 1976).

22. Prosser, supra note 5, at 502. To illustrate this point in the context of a pure coinparative neghigence system, assume that the jury returns only a general verdict for the plaintiff in the amount of $\$ 20,000$. In such a case, neither the court nor the parties would be able to determine whether the jury found the plaintiff $20 \%$ negligent and damaged in the amount of $\$ 25,000$, or $60 \%$ negligent and damaged in the amount of $\$ 50,000$, or some other combination. This uncertainty is also present when general verdicts are used under modified comparative negligence systems, although the range of possible numerical findings is somewhat narrower. 
tive negligence scheme. For these reasons, the special verdict has been designated "the very cornerstone of the comparative negligence concept." 23

When a general verdict form with special interrogatories is submitted to the jury, the court must fully inform the jury of the applicable comparative negligence law so that the jurors may conform tlie general verdict to the applicable law. When special verdicts alone are submitted, however, the jury's task is simply to return the fault and damages findings; the court performs the subsequent computations and enters a judgment in accordance with the comparative negligence law. Because the jury does not return a general verdict, it is not essential that the jurors be aware of the applicable law.

The special verdict findings of fact inust be objective, shielded froin the influence of juror bias and sympathy. Informing the jury of the legal effect of the special verdict answers may affect the objectivity of the jury in two important respects. First, in a inodified coinparative negligence system, if the jury is apprised of the effect of its percentage determinations on the outcoine of the case, it becomes aware of the bar to the plaintiff's recovery at the $50 \%$ or $51 \%$ contributory negligence level. With this knowledge, the jury, ratler than objectively allocatimg the fault, may adjust the percentage findings solely to enable or prevent a recovery. ${ }^{24}$ Second, under either form of comparative negligence, if the jury is informed that the court will reduce the total dainages in proportion to the plaintiff's neghigence to determine the ainount of recovery, the jury's formulation of the negligence or the dainages findings may be influenced. ${ }^{25}$

23. C. Heft \& C. Heft, Comparative Negligence Manual $\$ 8.10$ (1978). Special verdicts are utilized in comparative negligence cases in the federal courts, see FED. R. CIV. P. 49(a), and in a majority of comparative negligence states. The rules governing the submission of special verdicts in such cases are of three basic types: (1) special verdicts are mandatory, see, e.g., Lawrence v. Florida East Coast Ry., 346 So. 2d 1012 (Fla. 1977); KAN. STAT. ANN. $§ 60-258 a(b)$ (1976); (2) special verdicts are inandatory upon the request of one or both parties, see, e.g., MiNN. STAT. \& 604.01(1) (1978); and (3) special verdict submission is a matter of trial court discretion, see, e.g., Li v. Yellow Cab Co., 13 Cal. 3d 804, 824 n.18, 532 P.2d 1226, 1240 n.18, 119 Cal. Rptr. 858, 872 n.18 (1975); FED. R. CIv. P. 49(a).

A minority of comparative negligence states prohibits the submission of special verdicts in comparative negligence cases. See, e.g., N.H. Rev. STAT. ANN. § 507:7-a (Supp. 1979). Several of those states, however, specifically require the use of special interrogatories with general verdicts. See, e.g., Bradley v. Appalachian Power Co., 256 S.E.2d 879, 885-86 (W. Va. 1979); OHIO REv. CODE ANN. \& 2315.19(B) (Page 1981).

24. See note 93 infra.

25. See, e.g., Thomas v. Board of Township Trustees, 224 Kan. 539, 582 P.2d 271 (1978); Rosenthal v. Kolars, 304 Minn. 378, 231 N.W.2d 285 (1975). In Thomas the trial court had instructed the jury that the plaintiff was entitled to recover if his fault was less than $50 \%$, but not if his fault was $50 \%$ or more. The jury, with this knowledge, returned a special verdict allocating $49 \%$ of the fault to the plaintiff and $51 \%$ to the defendant township, resulting in a judgment for the 


\section{The Rule Against Informing}

\section{A. Adoption of the Rule Against Informing.}

Wisconsin was the first state to recognize the problems of informing the jury of the legal effects of special verdict answers in a comparative negligence action. This early recognition reflects the state's reputation as a pioneer in the areas of comparative negligence and special verdict submission. In 1890 , long before Wisconsm abandoned contributory negligence as a complete defense to a negligence action, its supreme court announced a rule against informing applicable to all civil trials in whicl special verdicts are submitted. ${ }^{26}$ The court noted that in order to secure special verdict answers free from bias or prejudice for or against a party, the jury "must not consider the effcct which their answers may have upon . . . the controversy or the parties." 27 In Banderob v. Wisconsin Central Railway 28 the supreme court laid out a general statement of the rule, holding that it constitutes "reversible error for the trial court by instruction . . . to inform the jury expressly or by necessary implication of the effect of [a spccial verdict answer] upon the ultimate right of either party litigant to recover or upon the ultimate liability of either party hitigant."29 The rule against informing was later extended to prevent counsel from arguing the effcct of the answers to the jury. ${ }^{30}$ Violation of the rule was a frequent object of judicial review in Wisconsin negligence cases. ${ }^{31}$

Informing the jury of the effect of its answers on the outcome of a neghigence case continued to be reversible error ${ }^{32}$ after the Wisconsin

plaintiff. In Rosenthal the jury had returned special verdicts setting the negligence of the plaintiff and the defendant at $35 \%$ and $65 \%$ respectively and the damages at $\$ 75,000$. Believing that the jury intended a recovery of the full $\$ 75,000$, the trial court reinstructed the jury solely on the effect of Minnesota's comparative negligence statute on the damages answer. The jury subsequently returned special verdicts containing the same negligence apportionment, but with dainages of $\$ 116,000$. These examples illustrate the propensity of juries to shape the special verdict answers to accomplish desired results when they are informed of the legal effects of the findings.

26. Ryan v. Rockford Ins. Co., 77 Wis. 611, 46 N.W. 885 (1890). See generally Annot., 90 A.L.R.2d 1040, 1049-51 (1963). .

27. Ryan v. Rockford Ins. Co., 77 Wis. at 616,46 N.W. at 886 .

28. 133 Wis. 249,113 N.W. 738 (1907).

29. Id. at 287,113 N.W. at 751 .

30. See Pecor v. Home Indem. Co., 234 Wis. 407, 291 N.W. 313 (1940).

31. See, e.g., Anderson v. Seelow, 224 Wis. 230, 271 N.W. 844 (1937); Van De Bogart v. Marinette \& Menominee Paper Co., 127 Wis. 104, 106 N.W. 805 (1906); Lyon v. City of Grand Rapids, 121 Wis. 609, 99 N.W. 311 (1904); Musbach v. Wisconsin Chair Co., 108 Wis. 57,84 N.W. 36 (1900); Ward v. Chicago, M. \& St. P.R.R., 102 Wis. 215, 78 N.W. 442 (1899); Coats v. Town of Stanton, 90 Wis. 130, 62 N.W. 619 (1895).

32. See, e.g., Blahnik v. Dax, 22 Wis. 2d 67, 125 N.W.2d 364 (1963); Erb v. Mutual Serv. Cas. Co., 20 Wis. 2d 530, 123 N.W.2d 493 (1963). See also De Groot v. Van Akkeren, 225 Wis، 105, 
legislature adopted a "49\%" comparative negligence system in 1931.33 Subsequently, however, the Wisconsin legislature became aware of the tendency of juries in comparative negligence cases to apportion fault equally between the plaintiff and the defendant and of the unfairness of the resulting dismissal of the plaintiff's complaint. ${ }^{34}$ One solution to this problem which the legislature considered was the abrogation of the rule agamst informing. ${ }^{35}$ If juries were made aware of the effect of a fifty-fifty apportionment, then the possibility of an unintended dismissal of the plaimtiff's claim might be diminislied. ${ }^{36}$ Another alternative was to amend the comparative negligence statute by substituting the "50\%" form for the "49\%" form. This substantive change would eliminate the unfairness problein by permitting the plaintiff to recover half his damages in the case of a fifty-fifty finding - a more equitable result than dismissal-without tainting the entire factfinding process by imdirectly 37 informing the jury of the effect of all possible apportionments. Furthermore, this solution would not disturb the judicially enunciated rule against informing, nor would it violate one of the purposes of special verdict submission: to prevent the arousal of bias or sympathy in the minds of the jurors. ${ }^{38}$ For these reasons, the Wisconsin legislature opted for the latter solution and in 1971 enacted a modified "50\%"

115,273 N.W. 725,730 (1937) (the court did not reach the question of whether such conduct was reversible error, but warned the trial court not to repeat the practice on retrial).

33. 1931 Wis. Laws ch. 242 (current version at WIS. STAT. \& 895.045 (1977)).

34. This unfair result, although often unintended by the jury, was compelled by Wisconsim's modified "49\%" form of comparative neghigence. The state legislature had made a rational policy decision that a claimant shonld not be permitted to recover in a neghigence action unless found to be less at fault than his opponent. The frequency of 50-50 findings caused the unfairness problem, however. See V. SchwarTz, Comparative Negligence $§ 3.5(B)$, at 77-78 (1974).

Reasons for the tendency of juries to apportion equally the negligence of the parties include (1) polarization of the jury, resulting in a compromise on the issue of neghigence, (2) imability of the jury to draw a finer factual distinction, (3) conflicting evidence that boils down to a credibility contest between the parties, and (4) the jury's realistic reflection of responsibility. The frequency of the 50-50 apportionment basically stems from the vagaries of human nature and the desire to "split the difference." See generally Fleming, supra note 10, at 245; Flynn, Comparative Negligence: The Debate, 8 TRIAL 49, 50-51 (May-June 1972).

35. The Wisconsin legislature considered, but did not enact, a proposal that would have required the trial judge to give an ultimate-outcome insiruction. See Smith, Comparative Negligence Problems with the Special Verdict: Informing the Jury of the Legal Effects of Their Answers, 10 LAND \& WATER L. REv. 199, 223-24 (1975).

36. A jury that is aware of the legal consequences of the special verdict answers, especially in a modified comparative neghigence jurisdiction, is less likely to apportion hastily the parties' negligence. $C f$. Seppi v. Betty, 99 Idaho 186, 193, 579 P.2d 683, 690 (1978) (an informed jury will closely examine the facts). But see text accompanying note 101 infra.

37. An instruction informing the jury of the resnlt of a 50-50 apportionment indirectly conveys information concerning the consequences of a finding of greater or lesser degrees of negligence.

38. See text accompanying note 3 supra. 
comparative negligence system. ${ }^{39}$ Notwithstanding this change, and despite persistent criticism, ${ }^{40}$ Wisconsin still recognizes the rule against informing. 41

The consensus among the states until the 1970s was that the Wisconsin rule was a necessary component of special verdict procedure in neghigence actions. Once the rule against informing became firmly entrenched in the Wisconsin courts at the turn of the century, recognition by other states soon followed. ${ }^{42}$ Informing the jury was held to be reversible error in neghigence actions whether the information was conveyed by the court ${ }^{43}$ or by counsel. ${ }^{44}$ When the states began to adopt comparative negligence systeins, the rule against informing remained. ${ }^{45}$ State lawmakers apparently beheved that retaining the Wisconsin rnle was consistent with the equitable goals that inspired the adoption of the comparative negligence primciple. Until the 1970s every state legislature and every state court of last resort to consider the rule against informing adopted the Wisconsin approach. The Wisconsin rule was

39. 1971 Wis. Laws ch. 47 (codified at WIs. STAT. § 895.045 (1977)).

40. See, eg., Kobelinski v. Milwaukee \& Suburban Transp. Corp., 56 Wis. 2d 504, 526-27, 202 N.W.2d 415, 428 (1972) (Hallows, C.J., concurring); Vincent v. Pabst Brewing Co., 47 Wis. 2d 120, 139, 177 N.W.2d 513, 522 (1970) (Hallows, C.J., dissenting); Ryan, Are Instructions Which Inform the Jury of the Effect of Their Answers Inimical to Justice?, 1940 WIS. L. REv. 400.

41. The Supreme Court of Wisconsin responded to numerous arguments in derogation of the rule against informing in McGowan v. Story, 70 Wis. 2d 189, 234 N.W.2d 325 (1975). The court, in upholding the trial judge's refusal to grant requests by both the plaintiff and the jury to give an ultimate-outcoine instruction, summarized the basic principles of the Wisconsin rule:

[A]ny change in the rule [against informing] would be contrary to the established basis for the use of juries, particularly in negligence cases.

...

... [T] law should be applied to the facts found. It is not the function of a jury in a case between private parties on the determination of comparative negligence to be influenced by sympathy for either party, nor should it atteinpt to inanipulate the apportioument of negligence to achieve a result that may seem socially desirable to a single juror or to a group of jurors.

Id. at 197-98, 234 N.W.2d at 329. See also Shawver v. Roberts Corp., 90 Wis. $2 \mathrm{~d}$ 672, 280 N.W.2d 226 (1979).

42. See, eg., Morrison v. Lee, 13 N.D. 591,102 N.W. 223 (1904); McFađdin v. Hebert, 118 Tex. 314, 15 S.W.2d 213 (Tex. Comm'n App. 1929, holding approved).

43. See, e.g., Rohr v. Henderson, 207 Kan. 123, 483 P.2d 1089 (1971); McCourtie v. United States Steel Corp., 253 Minn. 501, 93 N.W.2d 552 (1958); Smith v. Capital Fin. Co., 169 Ohio St. 11, 157 N.E.2d 315 (1959); Texas \& P. Ry. v. Hancock, 59 S.W.2d 313 (Tex. Civ. App. 1933).

44. See, eg., International Harvester Co. v. Pike, 249 Ark. 1026, 466 S.W.2d 901 (1971); Ferderer v. Northern Pac. Ry., 77 N.D. 169, 42 N.W.2d 216 (1950); Texas \& P. Ry. v. Edwards, 36 S.W.2d 477 (Tex. Comm'n App. 1931, holding approved).

45. See Argo v. Blackshear, 242 Ark. 817, 416 S.W.2d 314 (1967); Simpson v. Anderson, 186 Colo. 163, 526 P.2d 298 (1974); Avery v. Wadlington, 186 Colo. 158, 526 P.2d 295 (1974); Holland v. Peterson, 95 Idaho 728, 518 P.2d 1190 (1974); McGinn v. Utah Power \& Light Co., 529 P.2d 423 (Utah 1974); Woodward v. Haney, 564 P.2d 844 (Wyo. 1977). See also TEx. R. CIv. P. 277 (proinulgated by the Supreine Court of Texas in 1973). 
entrenched as the clear majority rule. ${ }^{46}$

\section{B. Application of the Rule Against Informing.}

Soon after the Supreme Court of Wisconsm announced the rule agamst informing, courts began to carve exceptions out of the rule. These exceptions obviated the need for reversal im every case in which the jury was exposed to information concerning the legal effect of its special verdict answers and paved the way for the current movement toward abrogation of the rule.

The first modification adopted by the Wisconsin courts was the common-knowledge exception to the rule against informing. In Banderob v. Wisconsin Central Railway ${ }^{47}$ the Supreme Court of Wisconsin held that reversible error is not committed simply because "an intelligent juror might . . . ascertain from the judge's charge by inference the effect upon the case of his [special verdict] answer . . . ."48 The common-knowledge exception has been applied to information conveyed by the court ${ }^{49}$ or by counsel ${ }^{50}$ that is merely cumulative of the knowledge that an ordinary juror would possess at the conclusion of the trial. The advent of comparative negligence and its use of complex numerical findings makes it doubtful, however, that a juror would per-

46. No clear-cut rule has developed in the federal courts concerning whether the jury should be informed of the legal effect of special verdict answers. The decision that went the furthest toward adoption of the rule against informing is Thedorf v. Lipsey, 237 F.2d 190 (7th Cir. 1956). In Thedorf, a comparative negligence action, the court upheld the trial judge's refusal to instruct the jury on legal primciples and stated that knowledge of the effect of special verdict answers is not within the province of the jury. Id. at 193-94. This dicta strongly intimates that it would have been error to so instruct the jury. 9 C. Wright \& A. Miller, Federal Practice and ProceDURE § 2509, at 511 (1971).

The Wisconsin rule was explicitly rejected in Lowery v. Clouse, 348 F.2d 252 (8th Cir. 1965), a negligence action tried under Minnesota law prior to the state's adoption of a comparative fault system. The court, in an opinion by Chief Judge, now Justice, Blackmun, noted the proscription of ultimate-outcome instructions in Texas and Wisconsin, but deemed that rule inapplicable in the federal courts. Lowery distinguished federal special verdict procedure under rule 49, FED. R. Crv. P. 49, which gives the trial judge discretion to choose the form of the submitted verdict, from the practice of mandatory special verdict submission in those states. A rigid rule against informing was thought to be contrary to the significant amount of discretion granted to federal judges by the federal rules. 348 F.2d at 260-61. See also Porche v. Gulf Miss. Marine Corp., 390 F. Supp. 624 (E.D. La. 1975) (Jones Act action).

47. 133 Wis. 249,113 N.W. 738 (1907).

48. Id. at 268-69, 113 N.W. at 744 (interpreting Chopin v. Badger Paper Co., 83 Wis. 192, 53 N.W. 452 (1892)). See also Swiergul v. Town of Suamico, 204 Wis. 114, 235 N.W. 548 (1931).

49. See, e.g., Wright v. Covey, 233 Ark. 798, 801-02, 349 S.W.2d 344, 347 (1961); Sullivan v. Minneapolis, St. P. \& S.S.M. Ry., 55 N.D. 353, 369, 213 N.W. 841, 847 (1927); Finck Cigar Co. v. Campbell, 134 Tex. 250, 253, 133 S.W.2d 759, 760 (Tex. Comm'n App. 1939, holding approved).

50. See, e.g., Reichert v. Northern Pac. Ry., 39 N.D. 114, 147, 167 N.W. 127, 138 (1917); McFaddin v. Hebert, 118 Tex. 314, 323-24, 15 S.W.2d 213, 217 (Tex. Comm'n App. 1929, holding approved). 
ceive the effect of the negligence and damages answers on the outcome of a case from knowledge gleaned during the trial alone. ${ }^{51}$

A related exception to the rule against informing is the submission of conditional special verdict questions, which require an answer from the jury only if specified previous questions have been answered in a particular way. Although conditional questions imdirectly inform the jury of the legal effect of the previous answer or answers, it is not always reversible error to submit questions conditionally. ${ }^{52}$ In Schroeder v. Rainboldt ${ }^{53}$ the Commission of Appeals of Texas observed that conditional submission is permissible if the jury is not thereby informed of the effect of previous answers that determine the case. ${ }^{54}$ Moreover, reversal because of the rule against informing is unnecessary when the condition does not convey to the jury information outside the jury's common knowledge. 55 Both the conditional-question exception and the common-knowledge exception thus restrict the scope of the rule against informing in situations in which strict application of the rule does not appreciably aid in the attainment of objective findings of fact.

Some states, although expressly recognizing the Wisconsin rule, have limited its application to prohibit only blatant violations. These states have given trial courts the discretion to determine whether to inform the jury in a particular situation. Texas's current application of the rule against informing illustrates this development. In 1973, the Texas legislature adopted a modified " $50 \%$ " comparative negligence system..$^{56}$ The Supreme Court of Texas responded in the same year by annending rule 277 of the Texas Rules of Civil Procedure:57

The court shall not in its charge . . . advise the jury of the effect of their answers, but the court's charge shall not be objectionable on the ground that it incidentally . . . advises the jury of the effect of their answers where it is properly a part of an explanatory instruction or definition. ${ }^{58}$

51. See notes $88-89$ infra and accompanying text.

52. See Schroeder v. Rainboldt, 128 Tex. 269, 279, 97 S.W.2d 679, 684 (Tex. Comm'n App. 1936, holding approved); Grasso v. Cannon Ball Motor Freight Lines, 125 Tex. 154, 161, 81 S.W.2d 482, 487 (Tex. Comm'n App. 1935, holding approved).

53. 128 Tex. 269, 97 S.W.2d 679 (Tex. Comm'n App. 1936, holding approved).

54. Id. at 279, 97 S.W.2d at 684; accord, Grieger v. Vega, 153 Tex. 498, 502, 271 S.W.2d 85, 87 (1954); Continental Oil Co. v. Barnes, 97 S.W.2d 494, 497 (Tex. Civ. App. 1936).

55. See Grieger v. Vega, 153 Tex. 498, 502, 271 S.W.2d 85, 87 (1954). See text accompanying notes 47-50 supra.

56. TeX. Rev. Civ. Stat. ANN. art. 2212a (Vernon Supp. 1980).

57. TEX. R. Crv. P. 277. The Supreme Court of Texas is vested with rule making authority by legislative enactment. See Tex. Rev. Crv. Stat. AnN. art. 173la (Vernon 1962).

58. TEX. R. CIV. P. 277. 
The amendment apparently was intended to ease the inflexibility of the Wisconsin rule. 59

Revised rule 277 tolerates any mcidental conveyance of legal information that would aid the jury's understanding of an issue. But comments directly referring to or compelling a particular outcome are still objectionable. 60 The vagueness of the revision and the failure of the Texas courts to enunciate specific parameters in the context of comparative negligence actions inevitably afford trial judges a great deal of latitude in applying the rule against informing. ${ }^{61}$

Although at one time the rule against informing was the clear majority rule among the states, ${ }^{62}$ even then several exceptions restricted its scope. The common-knowledge and conditional-question exceptions and the emphasis on trial court discretion curtailed application of the Wisconsm rule in situations where the rule was largely unnecessary. These inodifications substituted a inore flexible approach for the rigid Wisconsim approach of reversible error. The weakened rule, however, was susceptible to the argument that little difference exists between discretion not to apply the rule and no rule at all.

59. The revision may have been motivated by the experience of the Texas courts with the rule against informing in a comparative negligence context. In a series of cases tried under the Federal Employers' Liability Act, 45 U.S.C. $\$ \$ 51-60$ (1976), the Texas courts attempted to reconcile the state's practice of mandatory special verdict submission, see TEX. R. CIv. P. 277, and its recognition of the rule against informing, see the cases cited in notes 42-44 supra, with the FELA's requirement that "damages shall be dimmished by the jury," 45 U.S.C. $\$ 53$ (1976). Initially the courts found error in informing the jury that the damages were to be diminished im proportion to the plaintiff's negligence. See Texas \& P. Ry. v. Jefferson, 131 S.W.2d 175 (Tex. Civ. App. 1939); Panhandle \& S.F. Ry. v. Sedberry, 46 S.W.2d 719 (Tex. Civ. App. I932). The Texas courts eventually retreated from this position. In Texas \& N.O. Ry. v. Timer, 262 S.W.2d 769 (Tex. Civ. App. 1953), the court of civil appeals found no error in the form of a question calling for the amount by which the damages should be reduced as a result of the plaintiff's negligence. This holding was premised on the fact that the question did not explicitly refer to the jury's answer to the total dainages question. Id. at 773 .

60. Pope \& Lowerre, The State of the Special Verdict-1979, 11 ST. MARY's L.J. 1, 42-44 (1979); Pope \& Lowerre, Revised Rule 277-A Better Special Verdict System for Texas, 27 Sw. L.J. 577, 589-90 (1973); see Scott v. Atchison, T. \& S.F. Ry., 572 S.W.2d 273, 280 (Tex. 1978) ("the explanatory instruction slould focus the effect of the concept on the relevant issues that are to be considered, but without reference to the result thereof'); Gulf Coast State Bank v. Emenhiser, 562 S.W.2d 449, 453 (Tex. 1978) ("The jury's concern is to find disputed facts, rather than to achieve a particular result," and thus an instruction that if the jury found certain facts, then judgnent should be for a particular party, was impermissible).

61. Two other states, Idaho and Minnesota, conditioned the application of the rule against informing on a grant of trial court discretion. See Cassia Creek Reservoir Co. v. Harper, 91 Idaho 488, 491, 426 P.2d 209, 211 (1967); Patterson v. Donahue, 291 Minn. 285, 288, 190 N.W.2d 864, 866 (1971).

62. See text accompanying notes $42-46$ supra. 


\section{Abrogation of the Rule Against Informing-The Emergence of a New Majority Rule.}

As the principle of comparative negligence became widely recognized im the early 1970s, the states observed that the role of the jury in a negligence action had changed. Rather than answer simple yes or no questions regarding the negligence of the parties, the jury was now called on to quantify specific findings of relative fault. Clearly, courts placed more trust in the jurors and judicial control over the jury diminished.

The principle of damage apportionment was predicated on its inherent fairness, and many believed that it was inconsistent with that purpose to "blindfold" the jury and deprive it of knowledge of the legal effect of the special verdict findings. Consequently, a number of coinparative negligence states chose to reject the rule against informing and to permit the jury to be apprised of legal information in comparative negligence actions.

Eight states have abrogated the Wisconsin rule in comparative negligence actions by statute or procedural rule. Most of the statutes require that the jury be inforined of the legal effect of its findings. ${ }^{63}$ The other statutes merely permit the jury to be informed, but require ultimate-outcoine instructions upon the request of a party to the action. ${ }^{64}$ In 1973 Minnesota anended its state rules of civil procedure to grant wide discretion to trial courts in informing the jury. ${ }^{65}$ The amendment provides that in all comparative neghigence actions:

[T] he court shall inform the jury of the effect of its answers to the percentage of negligence question and shall permit counsel to comment thereon, unless the court is of the opinion that doubtful or unresolved questions of law, or complex issues of law or fact are involved, which may render such instruction or comment erroneous, misleading or confusing to the jury. ${ }^{66}$

A grant of trial court discretion to determine in each case whether the factfinding function would be better perfonned by an unenlightened jury thus qualifies the general mandate to inform. ${ }^{67}$

63. See Colo. Rev. Stat. § 13-21-111(4) (Supp. 1978); Conn. Gen. Stat. § 52-572h(b) (1981); Hawall Rev. STat. § 663-31(d) (1976); OR. Rev. STat. § 18.480(2) (1979).

Colorado courts have interpreted the Colorado statute to mean that a trial court's failure to give the requisite instruction is reversible error. See Loup-Miller v. Brauer \& Assoc.-Rocky Mountain, Inc., 40 Colo. App. 67, 70, 572 P.2d 845, 847 (1977); Appelgren v. Agri Chem., Inc., 39 Colo. App. 158, 159, 562 P.2d 766, 767 (1977).

64. See Nev. Rev. Stat. § 41.141-2 (1979); N.D. Cent. Code § 9-10-07 (1975); Wyo. Stat. § 1-1-109(b)(iii) (1977).

65. MinN. R. Civ. P. 49.01(2).

66. Id.

67. The Hawaii statute, although couched in obligatory language, similarly accords the trial 
In 1978 the Supreme Court of Idaho became the first state court of last resort ${ }^{68}$ to reject the rule against informing. In Seppi $v$. Betty ${ }^{69}$ the court observed that jurors frequently adjust their special verdict answers to achieve a predetermined result. If the legal effect of the answers is not obvious, the jury will speculate, often incorrectly, about the legal effect and thereby subvert the factfinding process. ${ }^{70}$ This problem is accentuated in a modified " $49 \%$ " state by the attractiveness of the fifty-fifty allocation. The court reasoned, however, that an informed jury would be inore inclined to examine the facts closely rather than to settle convemently on a fifty-fifty apportionment. ${ }^{71}$ The court therefore held that informing the jury of the effect of a finding of 50\% negligence of the plaintiff is not reversible error.

The Seppi court was concerned about the accuracy and objectivity of the jury's findings of fact. Consequently, the court added the following provisos:

[W] conclude that the trial courts should be given discretion not to .. inform the jury in those cases where the issues are so coinplex or the legal issues so uncertain that such instructions would confuse or mislead the jury.

....

... [T]he trial court has broad discretion to order a new trial when it believes that the verdict . . . is a product of the jury's misunderstanding, prejudice or bias, or that the jury has failed to properly follow its instructions. ${ }^{72}$

judge the discretion to determine whether to give an ultimate-outcome instruction: "The court shall instruct the jury regarding the law of comparative negligence where appropriate." Hawall REv. STAT. \& 663-31(d) (1976) (emphasis added). Thus, Hawaii joins Minnesota (generally for informing) and Texas (generally against informing) in conditioning the application of its provision on the discretion of the trial court.

68. The first state court decision to reject exphicitly the rule against informing was decided in 1973 by the Colorado Court of Appeals. Simpson v. Anderson, 33 Colo. App. 134, 517 P.2d 416 (1973), rev'd, 186 Colo. 163, 526 P.2d 298 (1974). The Supreme Court of Colorado subsequently reversed this maverick decision and adopted a Wisconsin-type rule of reversible error. Simpson v. Anderson, 186 Colo. 163, 526 P.2d 298 (1974). The Colorado legislature had the last word, however, when it abolished the rule against informing in 1975. Colo. Rev. STAT. § 13-21-111(4) (Supp. 1980).

69. 99 Idaho 186, 579 P.2d 683 (1978). The trial court in Seppi granted the defendant a new trial because instructions were given that could have misled the jury about the effect of a finding of contributory negligence. The jury had found the plaintiff and defendant equally negligent, requiring a judgment for the defendant under Idaho's modified "49\%" statute, IDAHO CODE § 6801 (1979). 99 Idaho at 188, 579 P.2d at 684-85.

70. 99 Idaho at 193,579 P.2d at 690.

71. Id.

72. Id. at 195,579 P.2d at 692 . 
The Idaho approach established in Seppi is similar to that of Minnesota, which grants broad trial court discretion to choose whether to give an ultimate-outcome instruction in a particular case.

In the year Seppi was decided, the Supreme Court of Kansas also abrogated the rule against informing in the context of comparative negligence actions. In Thomas $v$. Board of Township Trustees ${ }^{73}$ the court articulated three reasons for permitting ultimate-outcome imstructions. First, the typical jury already has a good idea of the result of its answers. Second, speculation by an unknowledgeable jury may lead to a verdict not reflecting the jury's true intent, especially under the modified " $49 \%$ " form of comparative negligence. And third, the jury's function of providing a just result requires knowledge of the legal effect of the special verdict findings. ${ }^{74}$ The court predicted that enlightened jurors will do their best to follow the law as instructed and therefore held that "it is not error for a trial court . . . to inform the jury as to the legal effect of its answers in a comparative negligence case, where a general imstruction is given informing the jury of the theory and legal effect of comparative negligence. . . ."75 Thomas thus jomed Seppi in abrogating the Wisconsin rule solely in comparative negligence cases.

New Jersey is the most recent comparative negligence state to reject the rule agamst informing. The Supreme Court of New Jersey in Roman v. Mitchell ${ }^{76}$. stated that the jury's deliberations should not take place in a vacuum or under mistaken notions of the law. ${ }^{77}$ Echoing the words of the Idaho court in Seppi, the Roman court observed that an informed jury is better able to fulfill its factfinding function and held:

Hereafter, an ultimate outcome instruction should be given to a jury in [a comparative negligence] trial. However, in a complex case involving multiple issues and numerous parties, the trial court, in the exercise of sound discretion, could withhold the instruction if it would tend to mislead or confuse the jury. ${ }^{78}$

73. 224 Kan. 539, 582 P.2d 271 (1978). The trial court instructed the jury on the legal effiect of the special verdict answers. The jury assessed the fault of the plaintiff and the defendant township at $49 \%$ and $51 \%$ respectively, resulting in a judgment for the plaintiff under Kansas's nodified “49\%” statute, KAN. STAT. ANN. § 60-258a (1976). 224 Kan. at 540, 548, 582 P.2d at 273, 278-79.

74. 224 Kan. at 550, 582 P.2d at 280.

75. $224 \mathrm{Kan}$. at $551,582 \mathrm{P.2 \textrm {d }}$ at 280 . In a recent opinion, a lower court interpreted Thomas as promulgating a mandatory rule and noted that a trial court that refuses to give an ultinateoutcome instruction in Kansas faces "sure reversal." Cook v. Doty, 4 Kan. App. 2d 499, 500, 608 P.2d 1028, $1030(1980)$.

76. 82 N.J. 336,413 A.2d 322 (1980). The trial judge refused to give a requested ultimateoutcome charge. This ruling was upheld by the appellate division, Roman v. Mitchell, 165 N.J. Super. 68, 397 A.2d 729 (App. Div. 1979), rev'd, 82 N.J. 336, 413 A.2d 322 (1980), but reversed by the supreme court. Roman v. Mitchell, 82 N.J. 336, 413 A.2d 322 (1980).

77. 82 N.J. at 345,413 A.2d at 327 .

78. Id. at $346-47,413$ A.2d at 327 . 
The court further instructed the trial courts of the state to set aside the jury's findings if the judge concludes that the verdict is the product of bias, prejudice, or misunderstanding. ${ }^{79}$

The Wisconsin rule has thus fallen in disfavor in comparative neghigence states. With the advent and general acceptance of the comparative neghigence principle, the Wisconsin rule has yielded to a new movement in favor of enlightening the jury about the legal effects of its special verdict findings. Except for Wisconsin, Texas, and Arkansas, the bastions of the rule against informing, all but one of the last twelve states to rule expressly on the inatter have removed the jury's "blindfold." 80 In general, the state courts that have rejected the Wisconsim rule have chosen trial court discretion to inform the jury over an absolute requirement that ultimate-outcome instructions be given. The state statutes abrogating the rule against informing, however, tend to give less discretion to the trial court. ${ }^{81}$

\section{ARguments For AND Against the RULE AGAINST INFORMING}

The following discussion assesses the advantages and disadvantages of the Wisconsm rule im light of the purposes of special verdicts, the jury's factfinding task when special verdicts are used, and the jury's role in the equitable determination of civil claims. The discussion demonstrates that the abrogation of the rule against informing contravenes the intent of the comparative neghigence principle. When special verdicts are used in a comparative negligence action, the jury should not be informed about the legal effect of its answers.

One of the goals of special verdict submission is to assist the jury

79. Id. at 347,413 A.2d at 327 . For a useful analysis of the Roman decision, see 12 RuTGERS L.J. 365 (1981).

80. The states that have rejected the Wisconsin rule in the past decade are Colorado, Connecticut, Hawaï, Idaho, Kansas, Minnesota, Nevada, New Jersey, North Dakota, Oregon, and Wyoming. The highest court of Utah, the inost recent comparative neghigence state to embrace the rule against informing, see McGinn v. Utah Power \& Light Co., 529 P.2d 423 (Utah 1974) (applying Idaho law, but indicating that Utah law suggests the same result), recently expressed a desire to join the above states in abrogating the rule. In Lamkin v. Lynch, 600 P.2d 530 (Utah 1979), three of the five justices went on record as favoring a reassessment of McGinn. Four of the justices held, however, that the issue was first raised on appeal and thus not properly before the court. Id. at 533.

A lower court in Pennsylvamia recently held that a coinparative neghigence jury should be inforined of the effect of the special verdict answers. Peair v. Home Ass'n, $430 \mathrm{~A} .2 \mathrm{~d} 665$ (Pa. Super. 1981). The court approved the ultimate outcome instruction that was given by the trial judge and observed that such an instruction is "essential if the jury is to be able to apply the equitable considerations and arrive at the compromises that are an inherent part of the jury system." Id. at 672.

81. Sce text accompanying notes 63-64 supra. 
in rendering objective findings of fact. ${ }^{82}$ Because there is no general verdict against which to test the factual findings, the findings inust be free from bias, sympathy, or prejudice for or against either party. ${ }^{83} \mathrm{In}$ forming the jury of the legal effect of the answers is improper if the court subimits special verdicts, which are not wholly determinative of the right of recovery. ${ }^{84}$ The jury's task in a comparative neghigence action of assessing and quantifying the relative fault of the parties does not alter the basic purposes underlying special verdict subimission.

In Lowery v. Clouse ${ }^{85}$ the Court of Appeals for the Eighth Circuit raised a particularly bothersome argument. The Lowery opinion suggests that if a trial court is granted unlimited discretion to subinit either special verdicts, a general verdict with special interrogatories, or a general verdict, it may also submit a forn of verdict that combines attributes of two different verdict types. ${ }^{86}$ The court thus concluded that the trial court may, in its discretion, inforn the jury about the legal effect of special verdict answers.

There is no logical explanation why discretion to subinit any one of three verdict types warrants subinission of a synthesis of two of the types. Indeed, availability of a choice between verdict types militates in favor of a rule against informing when special verdicts are used. If a judge deems it to be in the parties' best interests to inforin the jury, a general verdict forn, perhaps accompanied by special interrogatories, should be subinitted and a general charge given. If such inforination would be undesirable in a particular case, special verdicts may be subimitted without a general charge. Giving an ultimate-outcoine instruction with the submission of special verdicts, however, nullifies the distinction between special verdicts and special interrogatories that accoinpany a general verdict.

The synthesis type of verdict approved in Lowery is unnecessary when the trial judge is aware of the distinct benefits of alternative verdict forms. Moreover, if special verdict subimission is mandatory under a state's comparative negligence law, the governmental body from

82. See text accompanying note 3 supra.

83. See McGowan v. Story, 70 Wis. 2d 189, 198, 234 N.W.2d 325, 329 (1975); Gay, "Blindfolding" the Jury: Another View, 34 TEx. L. REv. 368, 378 (1956).

84. See Smith v. Gizzi, 564 P.2d 1009 (Okla. 1977); Note, supra note 4, at 115-19, 132. On the other hand, when the jury returns a general verdict, it must know the legal effect of the answers to interrogatories in order to determine the issue of liability in accordance with the applicable law. See Thode, Comparative Negligence, Contribution Among Tort-Feasors, and the Effect of a Release-A Triple Play by the Utah Legislature, 1973 UTAH L. Rev. 406, 414.

85. 348 F.2d 252 (8th Cir. 1965).

86. See id. at 260-61. See also Smith, supra note 35, at 217-20; 43 MiNN. L. Rev. 823, 824-25 (1959). The Lowery case is discussed at note 46 supra. 
which the law emanated nost likely intended a specific division of responsibility between judge and jury. The issue of liability has been removed from the jury's consideration. Thus, abrogation of the rule agamst informing is imconsistent with mandatory special verdict submission in comparative negligence actions. ${ }^{87}$

A state should prescribe the use of the type of verdict that comports with the desired role of the jury under the state's comparative neghigence law. The jury should be instructed only to the extent that it is proper under the type of verdict selected. Consequently, states that want to inform the jury in all cases should provide for mandatory general verdict submission im comparative negligence trials. States willing to give discretion to trial judges to determine whethcr to inform the jury im a particular case sliould provide for discretionary special or general verdict submission. A jurisdiction should adopt a consistent policy regarding verdict submission and the accompanying jury instructions.

Abrogation of the rule against informing is imconsistent with the jury's task of objective factfinding in comparative negligence cases in which special verdicts are used. As a general proposition, the average juror does not, prior to trial, know the effect of comparative negligence findings on the outcome of the case. ${ }^{88}$ This information therefore may not be conveyed to the jury under the traditional common-knowledge exception to the rule against informing. ${ }^{89}$ In a particular case, lowever, if the jury already knows the legal effect of the percentage findimgs, an ultimate-outcome instruction unnecessarily restates the jury's prior knowledge. In the more typical case in whicls the jury does not

87. The argument that informing the jury is inconsistent with the purposes of special verdict submission is relevant to civil trials generally and is not limited to comparative negligence actions in particular.

88. See Note, supra note 4, at 118. But see Thomas v. Board of Township Trustees, $224 \mathrm{Kan}$. $539,550,582$ P.2d 271, 280 (1978). In a modified comparative negligence state, it is highly unlikely that the potential jurors are aware of the $50 \%$ or $51 \%$ bar to the plaintiff's recovery. See Note, Informing the Jury of the Effect of Its Answers to Special Verdict Questions-The Minnesota Experience, 58 MINN. L. REv. 903, 929 (1974) (referring to Minnesota's “49\%" statute as "probably a mystery to the average juror"). Moreover, although the typical juror may perceive that the percentage findings will have some effect on liability, it is doubtful that a juror will comprehend the specific nature of the reduction by the court.

89. For a discussion of the common-knowledge exception, see text accompanying notes 47-50 supra. The exception, although applied frequently in negligence cases in which contributory negligence was a coinplete defense, is largely irrelevant under a comparative negligence systein. The primary reason for the difference is that with contributory neghigence the special questions are generally answered either "yes" or "no." It would be difficult for a juror to sit through an entire trial and not be able to discern whose side a particular answer will benefit. See Green \& Smith, Negligence Law, No-Fault, and Jury Trial-I, 50 TEx. L. Rev. 1093, 1113-14 (1972). See also Comment, Special Verdicts: Rule 49 of the Federal Rules of Civil Procedure, 74 YALE L.J. 483, 493 (1965). On the other hand, the numerical answers to special verdict questions in coinparative negligence cases are not conducive to such perceptions. 
know the legal effect of the percentage findings, conveying such information during the trial adversely affects the jury's factfinding role.

The courts that have rejected the Wisconsin rule have expressed the concern that uninformed jurors, anticipating the legal effcct of the numerical findings, will speculate incorrectly and render a verdict that does not reflect the jury's true intent. ${ }^{90}$ They contend that rather than rely on the jurors' chance understanding of the state's comparative neghigence law, the trial court should inform the jury of the effect of the findings on the outcoine of the case. ${ }^{91}$ This argument fails, however, to address the real problem facing the courts in such situations. The concern should not be with the possibility that an uninformed jury will speculate incorrectly, but instead with the tendency to speculate itself. An outcome-oriented jury, bent on manipulating the special verdict findings in order to achieve a desired result, functions beyond its contemplated role in a comparative negligence system whether or not it is correct in its appraisal of the legal effect of the answers.

One commentator has urged that a jury is less likely to manipulate the factual findings under a comparative negligence system tlian under a contributory neghigence system because the former is more consistent with a jury's notion of fairness. ${ }^{92}$ Logic indicates, however, that a jury bent on achieving a particular result would be as inclined to adjust the findings in a coinparative neghigence system as it would under the allor-nothing system. ${ }^{93}$ The difference is that the probability of an unintendcd result is much greater under a comparative neghgence system. ${ }^{94}$ For this reason, the jury should be prevented from adjusting the percentage findings to achieve a predetermined result. The rule against informing is a step toward eliminating jury manipulation because it removes the tools used by the jury to accomplish such manipulation.

A return to the Wisconsin rule alone will not eliminate the tendency of juries to speculate about the outcome of tlieir special verdict

90. See Seppi v. Betty, 99 Idaho 186, 193, 579 P.2d 683, 690 (1978); Thomas v. Board of Township Trustees, 224 Kan. 539, 550, 582 P.2d 271, 280 (1978).

91. See Simpson v. Anderson, 33 Colo. App. 134, 139, 517 P.2d 416, 419 (1973), rev'd, 186 Colo. 163, 526 P.2d 298 (1974).

92. See Comment, McGinn v. Utah Power \& Light Co.-Jury Blindfolding in Comparative Negligence Cases, 1975 UtaH L. Rev. 569, 577.

93. For example, assume that a jury desires that the plaintiff recover a $\$ 10,000$ judgment in a particular case. If contributory neghigence is a complete defense, the jury will return a verdict finding no contributory neghigence and assessing the plaintiff's damages at $\$ 10,000$. Under a modified comparative negligence system, the plaintiff's fault will be assessed at something less than $50 \%$, with the gross damages finding adjusted accordingly. These examples illustrate that any outcome-oriented jury is apt under contributory negligence or comparative negligence to manipulate the factual findings to achieve the desired result.

94. See note 89 supra. 
answers. The rule against informing is only one of several safeguards that courts can use to prevent jury inanipulation of factual findings. Another safeguard is for trial courts to give stern instructions informing the jury of its proper role in trials in which special verdicts are submitted and cautioning the jury not to be concerned with the legal result of its findings. ${ }^{95}$ The response that juries would ignore such cautionary instructions and continue to speculate ${ }^{96}$ represents an unjustified distrust of jurors. ${ }^{97}$

Although the court can regulate the information conveyed to the jury during the trial, it cannot erase juror knowledge acquired prior to trial. One ineans of reducing the likelihood that such prior knowledge will affect the jury's verdict is the use of jury selection procedures intended to procure legally unsophisticated jurors. Another solution is to impleinent a jury rotation system designed to minimize the number of coinparative neghigence trials in which each juror serves. ${ }^{98}$ Retention of the rule against informing coinbined with these procedures will reduce the incidence of speculation about the legal effect of the percentage findings by juries in coinparative negligence cases. Reducing jury speculation will in turn lessen the jury's tendency to inanipulate the special verdict answers to accord with a prearranged result. The jury, therefore, will render more objective findings of fact as contemplated under the state's coinparative negligence scheme.

In Roman and Seppi the courts inaintained that an informed jury is better able to perform its factfinding function. ${ }^{99}$ Although an ultiinate-outcoine instruction inay result in a more considered apportion-

95. In McGowan v. Story, 70 Wis. 2d 189, 234 N.W.2d 325 (1975), the Supreme Court of Wisconsin gave the following advice to the trial courts of the state:

We suggest that the jury should be admonished, and impressed, that its function in a negligence case is factfinding only and that it is not its role to usurp the legislative function under the comparative negligence law or the judicial function in interpreting the comparative negligence law. It is the role of the judge, acting under the law, and not the jury, to implement the general policies of the comparative negligence statute.

Id. at 198-99, 234 N.W.2d at 330.

96. See Green, Blindfolding the Jury, 33 TEx. L. REv. 273, 281 (1955); Green \& Sinth, supra note 89 , at $1113-14$.

97. Opponents of the rule against informing argue that the rule is based on an inherent distrust of juries. See Comment, supra note 92, at 579. It is anomalous, however, to provide the jurors with information on the legal effect of their answers and at the same time to expect them not to inject bias into the process by manipulating the findings of fact in accordance with a prearranged result. See note 101 infra.

98. These procedures have apparently been successful in Wisconsin. See Decker, Some Random Observations About Comparative Negligence and the Trial Process in Wisconsin, 1 CoNN. L. REv. 56, 63 (1968).

99. See Seppi v. Betty, 99 Idaho 186, 193, 579 P.2d 683, 690 (1978); Roman v. Mitchell, 82 N.J. 336, 346, 413 A.2d 322, 327 (1980). 
ment of fault, ${ }^{100}$ the jury does not necessarily become a better factfinder. Instead, by moldimg its answers to reach a desired result or by confurming that its findings comport with a desired result, the jury becomes a law-finder. ${ }^{101}$

In rejecting the rule agamst informing, some courts have contended that under the rule the jury's deliberations take place in a vacuum. ${ }^{102}$ This argument is actually directed toward the propriety of special verdicts themselves. The jury's role is clearly different when special verdicts are used, because the deliberations are focused on the resolution of specific factual questions and not on the determination of the defendant's hability. ${ }^{103}$ In any case, the jury does not operate in a vacuum while performing its factfindmg function in a comparative negligence action. It is instructed on the legal rules and definitions ${ }^{104}$ to be applied to the underlying facts of the case in order to derive the special verdict findimgs. Therefore, under the Wisconsim rule the jury is fully trusted as a factfinder.

Informing the jury about the legal effect of the percentage findings may confuse the jury unnecessarily in the performance of its factfinding duties. ${ }^{105}$ The jury's task under a comparative negligence system already entails a great deal of responsibility. ${ }^{106}$ Although jurors faith-

100. See note 36 supra.

101. See McGowan v. Story, 70 Wis. 2d 189, 198, 234 N.W.2d 325, 329 (1975); Denton, Informing a Jury of the Legal Effect of Its Answers, 2 ST. MARY'S L.J. 1, 10 (1970).

Some of the judicial decisions that reject the rule against informing purport to restrict the jury's ability to manipulate the findings by leaving to the trial court the discretion to set aside findings that are based on bias or misunderstanding. See Seppi v. Betty, 99 Idaho 186, 195, 579 P.2d 683, 692 (1978); Roman v. Mitchell, 82 N.J. 336, 347, 413 A.2d 322, 327 (1980). This restriction is not an effective restranit on jury manipulation for several reasons. First, jury manipulation is nearly impossible to detect. Cf. Kalven, The Jury, the Law, and the Personal Injury Damage Award, 19 OHo ST. L.J. 158, 167 (1958) (jury compromise on liability and damages under contributory negligenee is often impossible to detect). Second, even if sympathy or misunderstandimg appears to exist, the trial court cannot investigate the inatter further because of legal restramts on verdict impeachment. See, eg., Complete Auto Transit, Inc. v. Wayne Broyles Eng'r Corp., 351 F.2d 478 (5th Cir. 1965). Finally, the only effective means of setting aside the verdict is for the court to declare a mistrial. This solution seems adequate, but it is anomalous to inform the jury of the legal effect of its factual findings and to set aside the verdict when such information is put to use. In any event, this solution is also available under the Wisconsin rule and its use would at least be consistent with the purposes of that rule.

102. See Porche v. Gulf Miss. Marine Corp., 390 F. Supp. 624, 632 (E.D. La. 1975); Roman v. Mitchell, 82 N.J. 336, 345, 413 A.2d 322, 327 (1980).

103. See text following note 23 supra.

104. For example, negligence, proximate cause, and riglit-of-way.

105. One of the purposes of special verdict submission is to reduce jury confusion caused by complex legal instructions. See Skidınore v. Baltimore \& O.R., 167 F.2d 54, 64-65 (2d Cir.), cert. denied, 335 U.S. 816 (1948).

106. The jury's factfinding duties are more pervasive in comparative negligence cases than in cases in which contributory negligence is a complete defense. In addition to determining the 
fully attempt to digest instructions, they may lack the legal training and experience needed to understand and apply comparative negligence law. ${ }^{107}$ Even if the jurors understand an ultimate-outcome charge, the injection of additional numerical considerations will unnecessarily complicate the jury's task. An informed jury that misunderstands the charge inay manipulate the factual findings based on a misperception of the coinparative negligence law. The inanipulation of special verdict answers to reach a result unintended by the jury is, ironically, the precise situation that the ultimate-outcome instruction is intended to prevent.

Opponents of the rule frequently argue that the jury's role in a civil trial is primarily to do justice and that a jury must be aware of the legal effects of its answers $\mathrm{m}$ order to achieve a "just" result. ${ }^{108}$ Unfortunately, however, when the jury manipulates the answers, it tends to overemphasize the miportance of the labels "plaintiff" and "defendant." 109 A jury that determines that the plaimtiff is entitled to recover solne damages often ignores the fact that the defendant may also have sustained dainages and is himself a potential plaimtiff. An emotional judgment for the plaintiff, simply because of his position as a plaintiff, precludes any contemporaneous or future recovery by the defendant.110

The notion that the jury's role is to apply a common-sense view of justice im rendering its verdict arose from the perceived need for juries to temper harsh rules of law in accordance with principles of equity and fairness."11 The "equity" argument, however, is not a criticism of

issues of negligence and proximate cause, the jury in a comparative negligence jurisdiction is responsible for expressing its determinations in terms of specific numerical percentages.

107. See Avery v. Wadlington, 186 Colo. 158, 161-62, 526 P.2d 295, 297 (1974). The confusion is increased when the court inerely reads the state's comparative negligence statute to the jury, as is inandated in North Dakota, N.D. CENT. CODE \& 9-10-07 (1975), without further elaboration or explanation.

108. See Porche v. Gulf Miss. Marine Corp., 390 F. Supp. 624, 632 (E.D. La. 1975); Thoinas v. Board of Township Trustees, 224 Kan. 539, 550, 582 P.2d 271, 280 (1978); Commeut, Civil Procedure: Informing Comparative Negligence Juries What Legal Consequences Their Special Verdicts Effect, 18 WASHBURN L.J. 606 (1979).

On the other hand, Judge Jerone Frank is highly critical of the perceived role of juries in civil trials to achieve justice in the face of unfair laws and refers to the practice as "jury lawlessness." See J. Frank, Courts on Trial 126-37 (1949).

109. See Note, supra note 4, at 120; Sample Special Interrogatory Forms, Symposium on Bradley v. Appalachian Power Co.-West Virginia Adopts Comparative Negligence, 82 W. VA. L. REv. 545, 548 app. n.5 (1980).

110. The doctrine of collateral estoppel prevents a subsequent adjudicatiou between the parties of the facts underlying the comparative negligence action. For a classic statement of the doctrine, see Cromwell v. County of Sac, 94 U.S. 351,353 (1876).

111. See J. Frank, Courts on Trial 127-33 (1949). 
the rule against informing, but of special verdicts generally. ${ }^{112}$ When special verdicts are submitted, the jury's role is limited to that of an objective factfinder. ${ }^{113}$ The jury's function of mitigating inflexible laws is relevant primarily in cases in which a general verdict is returned.

The equity arguinent is generally inapposite to comparative neghigence actions. The notion that juries should do justice in the face of harsh, unfair laws does not apply if the law involved is not inherently inequitable. Courts and legislatures have adopted comparative negligence laws to relieve the inequities of the all-or-nothing contributory neghigence defense. ${ }^{114}$ Thus, in a comparative negligence action, it is no longer desirable for a jury to mold the verdict to comport with justice.

Comparing the effect of giving an ultimate-outcoine instruction with the jury practice of rendering a coinpromise verdict provides further evidence that the rule against informing does not impede the jury's role of achieving justice. Prior to the widespread abrogation of the allor-nothing contributory negligence defense, juries in some states rendered compromise verdicts for plaintiffs whose negligence they deemed shight compared with that of the defendant. A de facto coinparative neghigence system thus existed whereby the jury expressly found no contributory neghigence but reduced the damages in proportion to the perceived fault of the plaintiff. Hence, the jury, which believed that contributory negligence was a harsh defense and desired that the plaintiff recover some ainount, would compromise the issues of hability and damages. 115

De facto jury application of comparative negligence, although morally justifiable as a means of ameliorating the imequitable contributory negligence defense, was largely unsuccessful in practice. In returning a compromise verdict, the jury ignored the court's charge on the law of contributory negligence and instead applied its own notions of fairness. This jury disregard of the law as instructed denigrated the judicial system. Because the jury accomplished indirectly what it was

112. See Statement of Mr. Justice Black and Mr. Justice Douglas, 374 U.S. 865, 867.68 (1963) (opposing the promulgation of FED. R. CIV. P. 49); Guinn, The Jury System and Special Verdicts, 2 ST. MARY's L.J. 175 (1970).

113. See text accompanying notes $82-83$ supra.

114. See text accompanying notes 5-7 supra.

115. See, e.g., Haeg v. Sprague, Warner \& Co., 202 Minn. 425, 281 N.W. 261 (1938); Alibrandi v. Helmsley, 63 Misc. 2d 997, 314 N.Y.S.2d 95 (Civ. Ct. N.Y. 1970); Karcesky v. Laria, 382 Pa. 227, 114 A.2d 150 (1955); Freshwater v. Booth, 233 S.E.2d 312 (W. Va. 1977). For helpful discussions of the compromise verdict phenomenon in negligence cases, see J. ULMAN, A JUDGE TAKES THE STAND 30-34 (1933); Gilliam, Comparative Negligence Under Earlier Arkansas Statutes, 10 ARK. L. REV. 65, $65-66$ (1955-1956); Maloney, From Contributory to Comparative Negligence: A Needed Law Reform, 11 U. FLA. L. REv. 135, $144-45$ (1958). 
not legally permitted to do directly, the adjudicative process was no longer open and honest. This tainting of the adjudicative process resulted in a gap between the law in theory and the law in practice-a gap that eroded public confidence in the fairness of the legal systen. ${ }^{116}$

The tendency of juries to return coinpromise verdicts rendered the practical application of the law less uniform. Whether or not a particular jury would apply the law as instructed could not be predicted in advance. As a result, contributory neghigence was a complete defense in soine cases, but not in others. ${ }^{117}$ Furthermore, the level of tolerance accorded to jury application of de facto comparative negligence varied greatly ainong courts. Many courts rejected coinpromise jury verdicts in theory, but tolerated thein in practice, at least when the issue of liability was sufficiently in doubt. ${ }^{118}$

Informing the jury of the legal effect of its findings of fact in a comparative neghigence action is analogous to the de facto coinparative negligence practice with respect to the effect on the judicial process. Support for informing the jury is based, in part, on a desire for the jury to apply a community sense of justice. ${ }^{119}$ In other words, an informed jury is capable of either inolding the percentage findings when it be-

116. In short, the compromise-verdict practice was premised on disrespect for the law. Fleming, supra note 10, at 242-43; Heft \& Heft, The Two-Layer Cake: No Fault and Comparative Negligence, 58 A.B.A.J. 933, 934 (1972).

117. See Gay, supra note 83, at 378; Kalven, Comments on Maki v. Frelk-Comparative v. Contributory Negligence: Should the Court or Legislature Decide?, 21 VAND. L. REv. 897, 902-03 (1968).

118. Freshwater v. Booth, 233 S.E.2d 312, 315 (W. Va. 1977). See also Malone, Comments on Maki v. Frelk-Comparative v. Contributory Negligence: Should the Court or Legislature Decide?, 21 VAND. L. REv. 930, 934 (1968). The possibility that the trial court would direct a verdict for the defendant because of a holding that contributory negligence existed as a matter of law rendered the outcome of negligence cases even more unpredictable.

Similar in many respects to the compromise-verdict phenomenon in negligence cases is Arizona's approach to the contributory negligence defense. Article 18, section 5 of the Arizona Constitution provides that contributory neghigence "shall, in all cases whatsoever, be a question of fact and shall, at all times, be left to the jury." ARIz. Const. art. 18, § 5. The framers' intent apparently was to ameliorate the harshness of contributory negligence by establishing a de facto coinparative negligence system. See Note, Comparative Negligence in Arizona, 1979 ARIz. ST. L.J. 581,587 . Arizona courts have construed the provision as leaving the question of whether to apply the complete defense to the jury's discretion in all negligence cases. Thus, the jury is arbiter of both fact and law, Steed v. Cuevas, 24 Ariz. App. 547, 540 P.2d 166 (1975); State v. Cress, 22 Ariz. App. 490, 528 P.2d 876 (1974), and the trial court may not direct a verdict for the defendant, Heimke v. Munoz, 106 Ariz. 26, 470 P.2d 107 (1970). See generally Note, Contributory Negligence-Confiusion Out of Compromise, 13 ARZ. L. REV. 556 (1971).

Arizona's approach alleviates a serious disadvantage of the compromise-verdict practice. The approach is not based on jury disrespect for the court's charge because the instructions expressly inform the jury of its constitutionally derived power. But the other disadvantages of coinpromise-verdict recognition remain.

119. See text accompanying note 108 supra. 
lieves that the state's modified comparative negligence law would unfairly bar a recovery or adjusting the damages finding to allow the recovery of a predetermined amount. This behavior, like the compromise-verdict practice, depends on the jury's disregard for both the law of negligence as instructed by the court and the contemplated division of responsibility between judge and jury when special verdicts are used. Informing the jury, therefore, hinders judicial inonitoring of the jury's function. ${ }^{120}$ As a result, the law becomes as unpredictable in practice as it was when compromise verdicts were used.

Informing the jury and the compromise-verdict phenomenoin are also analogous in their impact on the development of the substantive law. Tolerance of compromise verdicts in negligence cases tended to ease public pressure for abrogation of the all-or-nothing contributory negligence defense. Some commentators even suggested that adoption of comparative negligence was unnecessary in view of the existing de facto coinparative negligence practice. ${ }^{121}$ Consequently, the comproimise-verdict practice delayed the adoption of the equitable comparative negligence principle by the states. ${ }^{122}$

Permitting the jury to be apprised of the effect of the percentage findings on the outcoine of the case may satisfy public demand for a change from a modified " $49 \%$ " to a inodified " $50 \%$ " comparative negligence systein because of the reduced incidence of fifty-fifty negligence apportionments. Informing the jury also may inhibit a change froin the inodified to the pure form by reducing the number of verdicts denying recovery to plaintiffs around the $50 \%$ negligence level. Thus, those who assert that the inodified comparative negligence cut-off merely lowers the arbitrary bar to recovery of contributory negligence ${ }^{123}$ and those who point out the unfairness of a fifty-fifty allocation under the modified " $49 \%$ " form 124 defeat their cause by supporting ultimate-outcoine instructions. A lesson should be derived from the unsuccessful compromise-verdict practice under contributory negligence. A similar preoccupation with "jury lawlessness" is unnecessary and should not be repeated under comparative negligence, a inuch inore equitable principle of tort law than contributory negligence.

120. See note 101 supra.

121. See Harkavy, Comparative Negligence: The Reflections of a Skeptic, 43 A.B.A.J. 1115, 1116-17 (1957); Powell, Contributory Negligence: A Necessary Check on the American Jury, 43 A.B.A.J. 1005, 1006 (1957).

122. Ironically, a practice that developed in response to the unfairness of contributory negligence actually resulted in the perpetuation of the all-or-nothing defense.

123. See text accompanying note 16 supra.

124. See text accompanying note 126 infra. 
Abrogation of the rule against informing frustrates the objective of special verdict submission and the intended division of responsibility between judge and jury under the comparative negligence scheme. Furthermore, giving an ultimate-outcone instruction does not facilitate, and in some cases detracts from, the jury's performance of its factfinding function. Finally, the jury's role of tempering harsh rules of law is not germane to comparative negligence actions in which special verdicts are used.

\section{A Suggested Procedural Framework for Retaining the RULE AGAINST INFORMING}

Permitting juries to be informed of the legal effect of their special verdict answers benefits plaintiffs in comparative negligence cases by preventing the dismissal of a negligence claim when sucl a result is not intended by the jury. ${ }^{125}$ However, informing the jury overcompensates plaintiffs for perceived inequities that can be solved througl more direct and reasonable inethods.

One reason the Seppi court rejected the rule against informing was the attractiveness of a fifty-fifty negligence apportionment to juries and the unfair result of such a finding in a inodified "49\%" coinparative negligence systein. ${ }^{126}$ The Seppi court recognized that in a state which has adopted the "49\%" form, defense counsel benefit by arguing to the jury for a fifty-fifty apportionment or more subtly for an "equitable" allocation in response to the "similar" faulty conduct of each party. If the jury follows the advice, this argument is extremely prejudicial to the plaintiff. The court can eliminate this prejudice by forbidding any reference by counsel to anything resembling an equal apportionment of negligence. ${ }^{127}$ The Wisconsin rule prohibits such a reference by precluding counsel from providing information to the jury that cannot be conveyed by instruction. ${ }^{128}$

A jury that is aware of the legal effect of its findings is less likely to apportion the fault liastily and equally between the plaintiff and the defcndant. ${ }^{129}$ The court inay take other ineasures, however, to ensure a careful, studied assessinent by the jury of the parties' neghigence. The court can einphasize to the jury the importance of the percentage findings by using firm instructions and by formulating clear special verdict

125. See Seppi v. Betty, 99 Idaho 186, 193, 579 P.2d 683, 690 (1978); Thomas v. Board of Township Trustees, 224 Kan. 539, 551, 582 P.2d 271, 280-81 (1978).

126. Seppi v. Betty, 99 Idaho 186, 193, 579 P.2d 683, 690 (1978).

127. See Note, supra note 4, at 126.

128. See text accompanying note 30 supra.

129. See note 36 supra. 
questions that are logically arranged. Relaxing the requirement of juror unanimity in special verdict answers ${ }^{130}$ might reduce the likelihood of a compromise fifty-fifty neghigence finding. Consideration of human nature, however, suggests that a finding of equal fault would still be the most common apportionment. ${ }^{131}$

Despite the apparent unfairness of a dismissal of the plaintiffs complaint in the case of a fifty-fifty neghigence allocation, there are certain justifications for this result. ${ }^{132}$ The legislature or highest court of a state, presumably aware of the advantages and disadvantages of modified "49\%" comparative negligence and the natural tendency of a jury toward equal apportionment of fault, nevertheless has exercised its constitutional authority to impose the 50\% barrier. Allowing a jury to mold its percentage findings to permit recovery when the jury believes the plaintiff is $50 \%$ or more at fault violates the legislative or judicial intent behind the modified "49\%" system. 133 This intent should be respected in the trial courts of the state.

The most logical and direct solution to the perceived unfairness of modified comparative negligence is to amend the state's substantive comparative neghigence law. The modified "49\%" form can be abandoned in favor of a nodified " $50 \%$ " comparative negligence system ${ }^{134}$ or a pure comparative negligence system. To attack as arbitrary the modified " $49 \%$ " form by sanctioning jury adjustment of the factual findings gives an unwarranted windfall to comparative neghigence plaintiffs.

Opponents of the rule against informing contend that giving ultimate-outcome instructions better enables the jury to consider separately the negligence and damages issues. ${ }^{135}$ They argue that these instructions thus prevent a "double deduction," whereby the jury reduces the dainages finding in accordance with the plaintiff's fault, unaware of the subsequent reduction by the court. ${ }^{136}$ Whether a complex, legalistic charge could have such an effect, however, is doubtful. An ultimate-outcome instruction may itself cause the jury to consider the issues of fault and dainages concurrently. And an informed jury miglit

130. See, eg., Wis. Stat. $\S 805.09$ (2) (1977) (five-sixths of the jurors must agree on all the special verdict answers).

131. See note 34 supra.

132. See note 15 supra and accompanying text.

133. See Note, supra note 4 , at 125 .

134. For a discussion of the Wisconsin experience, see text accompanying notes 32-39 supra.

135. Cf. Comment, supra note $\mathbf{9 2}$, at 578 (in a case in which the jury was not informed, the jurors mistakenly confused the negligence and damages findings).

136. See note 21 supra. 
answer the dainages question with an eye toward the plaintiff's total recovery in light of the negligence finding.

A more effective solution to the "double deduction" problein is to give instructions and special verdict questions that clearly inform the jury that its damages finding represents the total damages suffered by the plaintiff without regard to the plaintiff's fault. Although the jury is indirectly told that the percentage findings will have some bearing on the outcome of the case, the information conveyed clearly falls within the common-knowledge exception ${ }^{137}$ to the Wisconsin rule. The jury should not be instructed that the court will reduce the damages. This information is not common knowledge of the average juror and it may lead the jury to inflate the gross damages figure in anticipation of the subsequent reduction.

\section{CONCLUSION}

Informing the jury of the legal effect of its special verdict answers in a coinparative negligence action violates the comparative negligence scheme established by the legislature or highest court of a state and defeats the very object of special verdict submission. Giving an ultinate-outcome instruction to the jury, in effect, converts the special verdicts into a general verdict with special interrogatories. The trial court's function is thereby limited to the mechamical task of converting the jury's findings into a judgment that accords with the jury's expectations.

The rule against informing is most effective as a mandatory rule. ${ }^{138}$ If a state wishes to give trial judges the ability to decide whether to inform the jury, the state should grant judges discretion to submit either special or general verdicts. The decision whether to give an ultimate-outcome instruction then becomes a function of the type of verdict selected.

The judge inust instruct the jury clearly about the jury's role in the state's comparative neghigence sclieme. The court's charge should adinonish the jury neither to speculate about the legal result of the percentage findings nor to mamipulate the answers to accomplish a pre-

137. See notes $47-50$ supra and accompanying text.

138. Although an ultimate-outcome instruction may be desirable in unusual or coinplex cases, it is unlikely that adequate standards could be developed to denote the situations in which informing would be permissible. Provisions in Minnesota and a few other states that grant the trial court discretion not to inform the jury in certain situations have been criticized for lacking standards and inviting "fruitless appellate litigation." See Note, Informing the Jury of the Effect of Its Answers, supra note 88, at 929-32. The same complaint can be made about the Texas approach, which grants trial judges the discretion to inform the jury in some cases. See text accompanying notes 57-61 supra. 
determined result. The instructions must apprise the jury of the true meaning of the damages answer-that it represents the total damages mcurred by the plaintiff-and that the jury should formulate the damages answer without regard to the other findings of fact.

Recognition of the rule against informing, combimed with the use of trial procedures that apprise the jury of its intended role in the comparative negligence system, ensures an open and straightforward adjudication of negligence claims. Adoption of these procedural measures with special verdict submission enables the jury to reach objective and unbiased factual findings. These findings, when plugged into the comparative negligence formula by the trial judge, result in a judgnent based on objective fairness to all parties. And fairness is the hallmark of the comparative negligence principle.

Stuart F. Schaffer 